\title{
A CANADIAN FIELD TEST OF FINNISH AYRSHIRES : GROWTH AND REPRODUCTIVE PERFORMANCE
}

B. W. Kennedy, C. G. Hickman, G. R. Barr, M. G. Freeman, E. B. Burnside and R. L. ChiCoINE. - MacDonald College of McGill University, Sainte-Anne-de-Bellevue, Quebec, Canada.

An experiment was designed to obtain progeny test comparisons of Finnish and Canadian Ayrshire bulls used in Canadian herds. Eight bulls, 4 Finnish and 4 Canadian, were used in 60 cooperator herds located in the provinces of Quebec and Ontario. Among the 32 Quebec herds, $35 \mathrm{I}$ inseminations by Finnish bulls and 393 inseminations by Canadian bulls were performed. Percent nonreturn rates were 73 and 72 p. Ioo for the Finnish and Canadian bulls respectively.

Shortly after their birth, 83 bull calves were obtained from the cooperator herds and placed on a growth trial at a research station where average daily gain to $135 \mathrm{~kg}$, feed efficiency and carcass yield were measured. Progeny test results showed a growth advantage of $.35 \mathrm{~kg}$ per day for the Canadian bulls and Canadian bulls tended to be superior for feed efficiency. Little difference in carcass yield was noted. The experiment is continuing with level of milk production, growth rate and mature size of the female progeny as the traits of major interest.

\section{HERITABILITY ESTIMATES FOR MILK FLOWRATE IN GERMAN RED AND WHITE CATTLE}

\author{
W. Schlote. - Institut für Tierhaltung und Tierzüchtung der Universität Hohenheim. D.- $\mathbf{1 0 0 ( )}$ \\ Stuttgart $\approx 0$. Postfach 106 (BRD).
}

In Rheinland-Pfalz, a state in the West of the German Federal Republic, a routine procedure was used since 1969 to collect data on milk flow rate of heifers. The test was performed between third and fifth month of lactation, minimum milk yield required for testing was $5 \mathrm{~kg}$ per milking. By the socalled simple test procedure - the regular technician measured milk yield and milking time on the usual test-day-milk flow rate was determined as the average amount of milk per minute (kg/min.). Records of 14744 heifers were used for computation of regressions and nested analyses of variance.

Regression of milk flow rate on milk yield was $b=0.15$. This coefficient was used to correct milk flow to a milk yield of $8 \mathrm{~kg}$ per milking. Quadratic or cubic regressions did not fit the data better than linear regression. Influence of stage of lactation, i. e., days in milk, was very low.

Nested analysis of variance (heifers/herds/technicians/sires) yielded a high value for heritability $\left(h^{2}=0.6 \mathrm{I} \pm .08\right)$. This value was supposed to be inflated because of the unfavourable structure of the data. Analysis of a selected well-structured subset of the data yielded a very low heritability estimate for milk flow rate $\left(h^{2}=0\right.$. I0 \pm .08$)$ and a little higher estimate for the herdmate deviation $\left(h^{2}=0.20 \pm .10\right)$. Although most authors found higher estimates for milk flow rate these values are thought to be reliable for the simple test procedure. The low heritabilities shed new light on selection for this trait within cattle breeding programmes. In particular, the economic importance of milk flow rate must be reconsidered.

\section{I)IE BEDEUTUNG DER MELKBARKEIT FỨR DIE SELEKTION}

\section{J. Pogacar, (., Averdunk. - Kmetijski Institut Slovenije, Hacquetova 2, Ljubljana rugoslavia.}

In der vorliegenden Arbeit sind die Wirtschaftlichkeitskoeffizienten und, aufgrund der jeweiligen phänotypischen Standardeinheit die Relation zwischen Melkbarkeit und Milchmenge in verschiedenen Melksystemen geschätzt. Mithilfe einer Modellrechnung ist auch der genetische Fortschritt kalkuliert. Für die durchschnittlichen Bedingungen in Slowenien ist das standardisierte Verhältnis zwischen Milchmenge und Molkbarkeit mit I : $5-6$ bestimmt. Deswegen bringt eine Indexselektion auf beide Eigenschaften eine um 5-7 p. 100 grössere wirtschaftlichgenetische Verbesserung, als die alleinige Selektion auf Milchmenge. Etwa $1 / 3$ dieses Selektionerfolges ist für die Kosten der Melkbarkeitsprüfung aufzubringen. 